\title{
PENINGKATAN PENGETAHUAN IBU HAMIL DALAM MENJALANKAN KEBIASAAN BARU DI MASA PANDEMI
}

\author{
THE INCREASING KNOWLEDGE OF PREGNANT WOMEN \\ DURING NEW NORMAL IN PANDEMIC ERA
}

\author{
Siti Fatimah",Yudita Ingga Hindiarti, Kurniati Devi Purnamasari \\ Program Studi D-III Kebidanan, Fakultas Ilmu Kesehatan, Universitas Galuh \\ *Email: sitifatmah446611@gmail.com \\ (Diterima 03-08-2021; Disetujui 23-08-2021)
}

\begin{abstract}
ABSTRAK
Angka Kematian Ibu masih menjadi tantangan besar dalam situasi bencana Covid-19. Ibu hamil menjadi salah satu kelompok rentan risiko terinfeksi Covid-19 berkaitan dengan perubahan fisiologis selama kehamilan yang mengakibatkan penurunan kekebalan parsial. Pada studi awal sebelum kegiatan, ditemukan masih banyaknya ibu hamil yang tidak mengetahui tentang penerapan protokol kesehatan dalam menjalankan adaptasi kebiasaaan baru selama kehamilan. Upaya dalam mengatasi masalah yang ada selama masa kehamilan diperlukan melalui penyuluhan pemahaman ilmu pengetahuan tentang Covid-19, cara pencegahan dan penerapannya selama adaptasi kebiasaan baru pada masa pandemi terutama bagi ibu hamil. Metode yang digunakan dalam kegiatan ini berupa penyuluhan kesehatan dalam rangka meningkatkan pengetahuan pada ibu hamil dalam menjalankan adaptasi kebiasaan baru di masa pandemi. Penerapan metode kegiatan ini dibagi menjadi 3 tahapan, diantaranya sosialisasi, diskusi dan evaluasi kegiatan. Sejumlah 20 orang ibu hamil hadir dalam kegiatan ini dengan penerapan protokol kesehatan selama kegiatan berlangsung. Terdapat perbedaan signifikan pada pengetahuan ibu pada sebelum (pretest) dan setelah (posttest) kegiatan. Diharapkan kegiatan ini dapat menjadi kegiatan rutin sebagai upaya utilisasi peningkatan derajat kesehatan ibu hamil selama pandemi Covid-19.
\end{abstract}

Kata kunci : Pengetahuan, Ibu Hamil, Covid-19

\begin{abstract}
Maternal Mortality Rate is still a common challenge in the Covid-19 disaster situation. Pregnant women are one of high risk community of being infected with Covid-19, physiological changes that result in a partial decrease in immunity during pregnancy. Research studies are done to discover many pregnant women who did not known about the application of health protocols of Covid-19 in carrying out new habits during pregnancy. To overcome the problems that exist during pregnancy, it is necessary to provide information on the understanding of science about Covid-19, how to prevent and apply it in carrying out new habits during the pandemic, especially for pregnant women. The method used in this activity is in the form of health education in order to increase knowledge of pregnant women in adapting new habits during the pandemic. The application of this activity method is divided into 3 stages, including socialization, discussion and evaluation of activities. A total of 20 pregnant women attended this activity with the implementation of health protocols during the activity. There is a significant difference in mother's knowledge before (pretest) and after (posttest) activities. We hoped that this activity can become a routine activity as an effort to utilize the improvement of the health status of pregnant women during the Covid-19 pandemic.
\end{abstract}

Keywords: Knowledge, Pregnant Women, Covid-19

\section{PENDAHULUAN}

Di Indonesia, kematian ibu dan kematian neonatal masih menjadi tantangan besar dan perlu mendapatkan perhatian dalam situasi bencana Covid-19. Berdasarkan data dari Gugus Tugas Percepatan Penanganan Covid-19 per tanggal 14 September 2020, jumlah pasien terkonfirmasi Covid-19 sebanyak 221.523 orang, pasien sembuh sebanyak 158.405 (71,5\% dari pasien yang terkonfirmasi), dan pasien meninggal sebanyak 8.841 orang $(3,9 \%$ 
Peningkatan Pengetahuan Ibu Hamil dalam Menjalankan Kebiasaan Baru di Masa Pandemi Siti Fatimah,Yudita Ingga Hindiarti, Kurniati Devi Purnamasari

dari pasien yang terkonfirmasi) (Covid-19, 2020). Dari total pasien terkontamisasi positif Covid-19, sebanyak 5.316 orang (2,4\%) adalah anak berusia 0 - 5 tahun dan terdapat $1,3 \%$ di antaranya meninggal dunia. Untuk kelompok ibu hamil, terdapat 4,9\% ibu hamil terkonfirmasi positif Covid-19 dari 1.483 kasus terkonfirmasi yang memiliki data kondisi penyerta. Data ini menunjukkan bahwa ibu hamil, bersalin, nifas dan bayi baru lahir juga merupakan sasaran yang rentan terhadap infeksi COVID-19 dan kondisi ini dikhawatirkan akan meningkatkan morbiditas dan mortalitas ibu dan bayi baru lahir (Dashraath et al., 2020; Khaliq \& Phoswa, 2020; Sentilhes et al., 2020).

Kabupaten Ciamis sebagai salah satu kabupaten di Provinsi Jawa Barat berdasarkan data diketahui bahwa tahun 2020 jumlah total kasus positif sebanyak 252 orang, meninggal 12 orang, 70 orang positif aktif dengan rincian 14 orang pasien dirawat; sedangkan 169 orang dinyatakan sembuh. Menurut data Dinkes Ciamis ada 21 kecamatan di level merah. Penyebaran virus dan penambahan korban yang begitu cepat telah menjadi fokus seluruh lapisan masyarakat dan Pemerintah Daerah (Pemda) Ciamis. Pemda Ciamis menggalakkan pembatasan sosial dan isolasi mandiri, melakukan tes massal atau rapid test untuk mencegah penyebaran. Pemda Ciamis melalui Gugus Tugas Covid-19 juga menyusun pedoman pencegahan dan pengendalian Coronavirus Disease. Disebutkan bahwa langkahlangkah pencegahan Covid-19 di masyarakat meliputi: (1) melakukan cuci tangan menggunakan sabun dengan air mengalir (Cohen \& Corey, 2020); (2) mengkonsumsi makanan dengan gizi yang seimbang; (3) memakai masker yang benar; (4) menerapkan etika batuk dan bersin; dan (5) menjaga jarak (minimal 1 meter) dari orang yang mengalami gejala gangguan pernapasan (Yong \& Chen, 2020).

Berdasarkan hasil studi pendahuluan yang dilakukan di Puskesmas Wilayah Kerja Kelurahan Kertasari yang dilakukan dengan mewawancarai lima orang ibu hamil, hasilnya menunjukkan bahwa tiga dari lima orang yang diwawancarai belum mengetahui sepenuhnya tentang penerapan protokol kesehatan dalam menjalankan adapatasi kebiasaaan baru, dan dua orang lagi sudah terbiasa menerapkan protokol kesehatan di era adaptasi kebiasaan baru. Lebih lanjut berdasarkan data yang diperoleh dari Puskesmas Wilayah Kerja Kertasari dari 68 ibu hamil dua di antaranya terkonfirmasi positif Covid-19. Oleh karena itu, diperlukan peningkatan pengatahuan dalam bentuk penyuluhan kesehatan yang mengusung tema "Peningkatan Pengetahuan Ibu Hamil dalam Menjalankan Kebiasaan Baru di Masa Pandemi”. 


\section{BAHAN DAN METODE}

Metode yang digunakan dalam kegiatan ini berupa penyuluhan kesehatan dalam rangka meningkatkan pengetahuan ibu hamil dalam menjalankan adapatasi kebiasaan baru di masa pandemi. Penerapan metode kegiatan ini dibagi menjadi 3 tahapan, diantaranya sosialisasi, diskusi dan evaluasi kegiatan. Kegiatan ini berlangsung di Kelurahan Kertasari pada bulan Januari- Maret 2021 dengan peserta sejumlah 20 orang dengan penerapan protokol kesehatan selama kegiatan berlangsung. Rincian tahapan pelaksanaan kegiatan ini dijelaskan pada tabel 1.

Tabel 1 Metode Tahapan Pelaksanaan

\begin{tabular}{|c|c|c|c|}
\hline $\begin{array}{c}\text { Tahapan } \\
\text { Pelaksanaan }\end{array}$ & $\begin{array}{c}\text { Waktu } \\
\text { Pelaksanaan }\end{array}$ & Jenis Kegiatan & Indikator Capaian Kegiatan \\
\hline Tahap I & 20 Januari 2021 & $\begin{array}{lrr}\text { Sosialisasi dan } & \text { diskusi } \\
\text { kegiatan untuk } & \text { membuka } \\
\text { pemikiran mitra } & \end{array}$ & $\begin{array}{l}\text { Terbukanya pemikiran dan } \\
\text { pemahaman mitra atas penanganan } \\
\text { masalah }\end{array}$ \\
\hline Tahap II & 26 Februari 2021 & $\begin{array}{l}\text { Penyampaian materi dengan } \\
\text { metode penyuluhan kesehatan } \\
\text { tentang Covid-19, cara } \\
\text { pencegahannya, dan adaptasi } \\
\text { kebiasaan baru di masa } \\
\text { pandemi }\end{array}$ & $\begin{array}{l}\text { Dimilikinya pemahaman dan } \\
\text { peningkataan kemampuan Ibu hamil } \\
\text { dalam menerapkan kebiasaan baru di } \\
\text { masa pandemi }\end{array}$ \\
\hline Tahap III & 18 Maret 2021 & $\begin{array}{l}\text { Evaluasi kegiatan dan tindak } \\
\text { lanjut pasca kegiatan }\end{array}$ & $\begin{array}{l}\text { Mitra mampu mampu melaksanakan } \\
\text { dan menyebarluaskan informasi } \\
\text { tentang adaptasi kebiasaan baru }\end{array}$ \\
\hline
\end{tabular}

\section{HASIL DAN PEMBAHASAN}

Tahap pelaksanaan kegiatan ini dibagi ke dalam tiga bagian. Pada bagian pertama para peserta pelatihan diberikan tes untuk mengetahui kemampuan awal para peserta sekaitan dengan tema pengabdian ini yaitu tentang Covid-19 dan adaptasi kebiasaan baru. Pelaksanaan kegiatan pre-tes ini dengan cara menjawab pertanyaan-pertanyaan yang telah disusun berupa pilihan ganda sebanyak 20 pertanyaan yang bertujuan untuk mengukur pengetahuan awal mitra. Dari hasil pretes yang dilakukan terhadap peserta diperoleh gambaran pengetahuan mitra sebagaimana pada Tabel 2.

Tabel 2 Gambaran Pengetahuan Awal Peserta

\begin{tabular}{cccc}
\hline \multirow{2}{*}{$\mathrm{F}$} & \multicolumn{3}{c}{ Pengetahuan (Kategori\%) } \\
\cline { 2 - 4 } & Baik & Cukup & Kurang \\
\hline 20 & $20 \%$ & $40 \%$ & $40 \%$ \\
\hline
\end{tabular}

Berdasarkan Tabel 2, diketahui $20 \%$ atau sekitar 4 orang peserta memiliki pengetahuan yang baik, selain itu $40 \%$ atau sekitar 8 orang peserta memiliki pengetahuan cukup, dan kurang tentang adaptasi kebiasaan baru. Artinya, rata-rata adaptasi kebiasaan 
baru di masa pandemi belum dipahami dengan baik oleh ibu hamil di Kelurahan Kertasari Kabupaten Ciamis. Untuk mengatasi hal tersebut, maka dilanjutkan dengan tahap kegiatan berikutnya yaitu penyuluhan Kesehatan kepada Ibu hamil di Kelurahan Kertasari, Kabupaten Ciamis.

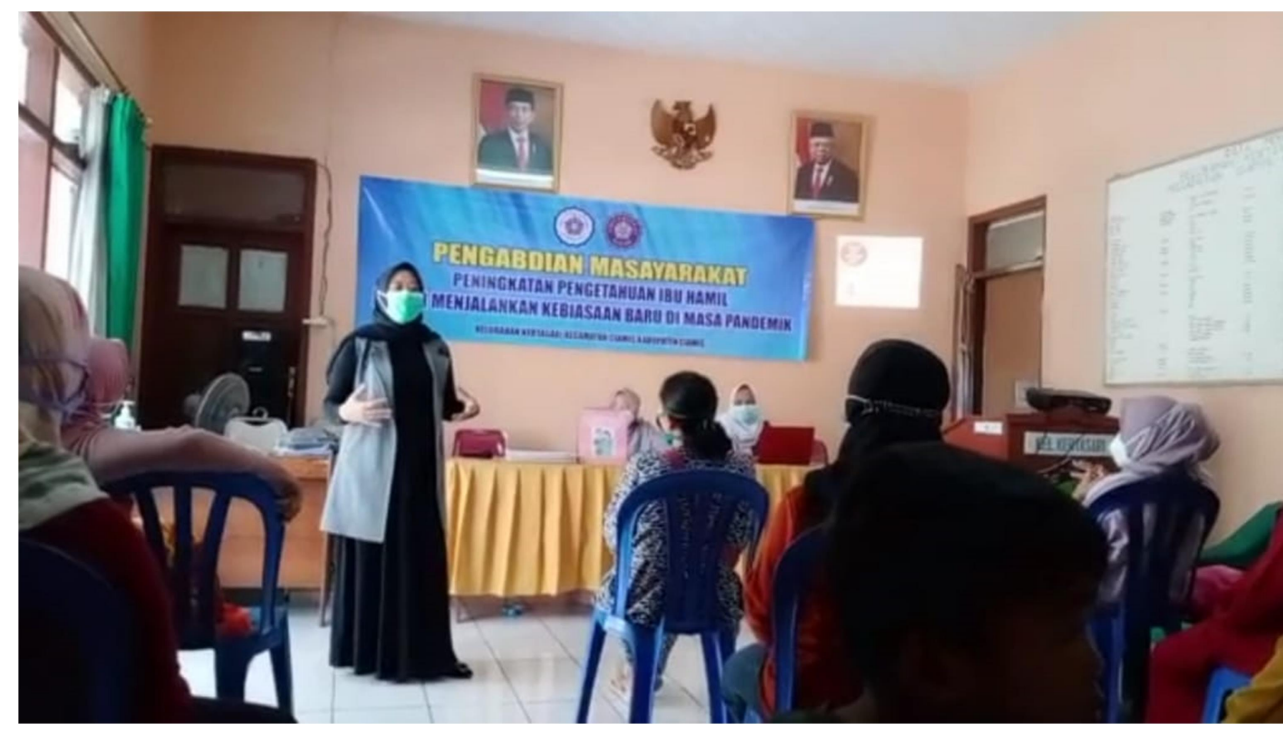

Gambar 1 Pemberian Materi Terhadap Peserta

Penyampaian materi diawali dengan menjelaskan tentang pengertian Covid-19. Hal ini dilakukan untuk memberikan pemahaman terhadap peserta tentang Covid-19. Materi berikutnya yang disampaikan kepada peserta adalah materi tentang pencegahan Covid-19. Hal ini ditujukan untuk memberikan pemahaman kepada peserta tentang langkah-langkah atau pencegahan Covid-19. Lebih lanjut setelah pembahasan ini disampaikan kebiasaan baru di masa pandemi sebagai salah satu upaya mencegah penyebaran Covid-19 yang biasa dikenal dengan 5M (Memakai masker, Mencuci tangan memakai sabun dan air mengalir, Menjaga jarak, Menjauhi kerumunan, Membatasi mobilisasi dan interaksi). Dengan penyampaian materi ini diharapkan semua peseta memahami dengan baik bagaimana cara menjalankan adaptasi kebiasaan baru di masa pandemi sehingga akan terhindar dari Covid19.

Setelah semua materi disampaikan, para peserta diberikan tes kembali sebagai evaluasi (post-test) untuk mengukur capaian kegiatan penyuluhan yang telah dilakukan. Berikut disajikan hasil post-test pada Tabel 3.

Tabel 3 Gambaran Pengetahuan Akhir Peserta

\begin{tabular}{cccc}
\hline \multirow{2}{*}{$\mathrm{F}$} & \multicolumn{3}{c}{ Pengetahuan (Kategori\%) } \\
\cline { 2 - 4 } & Baik & Cukup & Kurang \\
\hline 20 & $80 \%$ & $20 \%$ & $0 \%$ \\
\hline
\end{tabular}


Berdasarkan data pada Tabel 3, diketahui bahwa pengetahuan Ibu hamil tentang adaptasi kebiasaan baru di masa pandemi dari semua peserta yang mengikuti kegiatan tersebut $80 \%$ sudah memiliki pengetahuan yang baik, dan $20 \%$ masih memiliki pengetahuan yang cukup. Hal ini menunjukkan bahwa kegiatan penyuluhan yang dilakukan memberikan dampak positif terhadap peningkatan pengetahuan ibu hamil tentang adaptasi kebiasaan baru di era pandemi Covid-19.

Sebagaimana hasil analisa situasi yang dihadapi oleh mitra bahwa adanya kekurangpahaman ibu hamil dalam menjalankan adaptasi kebiasaan baru yang harus dilakukan selama kehamilan. Dengan meningkatnya pemahaman tersebut diharapkan kehidupan sosial ibu hamil akan lebih waspada tehadap penyebaran virus tersebut dan tidak terlalu tertekan dalam menjalankan adaptasi kebiasaan baru.

Selanjutnya, untuk lebih jelasnya dampak perubahan sosial yang terjadi pada mitra tersebut atas pelaksanaan program ini, secara kualitatif dapat diuraikan pada tabel 4 .

Tabel 4 Capaian Penerapan Program pada Kondisi Mitra

\begin{tabular}{lll}
\hline \multirow{2}{*}{ Tahap Pelaksanaan } & \multicolumn{1}{c}{ Kondisi Awal } & \multicolumn{1}{c}{ Kondikator Capaian } \\
\cline { 2 - 3 } & \multicolumn{1}{c}{ Tertutup dan masih tabu } & Terbuka dan mulai menerima \\
\hline Sosialisasi kegiatan & $\begin{array}{l}\text { Kurang jelasnya pemahaman ibu } \\
\text { hamil tentang virus corona }\end{array}$ & $\begin{array}{l}\text { Meningkatknya pemahaman ibu } \\
\text { hamil tentang virus corona }\end{array}$ \\
\hline Penjelasan tentang virus & Korona & Meningkatnya pengetahuan ibu hamil \\
Penjelasan tentang upaya & Kurangnya pengetahuan ibu hamil \\
pencegahan dan adaptasi & tentang adaptasi kebiasan baru & terhadap adaptasi kebiasaan baru \\
kebiasan baru & & \\
\hline
\end{tabular}

\section{KESIMPULAN DAN SARAN}

Pelaksanaan kegiatan pengabdian kepada masyarakat ini berjalan dengan baik dan lancar sesuai dengan rencana yang telah disusun. Secara umum seluruh peserta dapat menjelaskan penerapan kebiasaan baru di era pandemi Covid-19. Berdasarkan evaluasi yang dilakukan menunjukan adanya peningkatan signifikan pada pengetahuan ibu hamil tentang penerapan protokol kesehatan Covid-19 selama pandemi. Diharapkan kegiatan ini dapat menjadi kegiatan rutin sebagai upaya utilisasi peningkatan derajat kesehatan ibu hamil selama pandemi Covid-19.

\section{DAFTAR PUSTAKA}

Cohen, M. S., \& Corey, L. (2020). Combination prevention for COVID-19. American Association for the Advancement of Science.

Covid-19, S. (2020). Data Sebaran Covid-19. Satuan Penanganan Covid-19. https://covid19.go.id/ 
Dashraath, P., Wong, J. L. J., Lim, M. X. K., Lim, L. M., Li, S., Biswas, A., Choolani, M., Mattar, C., \& Su, L. L. (2020). Coronavirus disease 2019 (COVID-19) pandemic and pregnancy. American Journal of Obstetrics and Gynecology, 222(6), 521-531. https://doi.org/10.1016/j.ajog.2020.03.021

Khaliq, O. P., \& Phoswa, W. N. (2020). Is Pregnancy a Risk Factor of COVID-19? European Journal of Obstetrics \& Gynecology and Reproductive Biology.

Sentilhes, L., De Marcillac, F., Jouffrieau, C., Kuhn, P., Thuet, V., Hansmann, Y., Ruch, Y., Fafi-Kremer, S., \& Deruelle, P. (2020). COVID-19 in pregnancy was associated with maternal morbidity and preterm birth. American Journal of Obstetrics and Gynecology. https://doi.org/10.1016/j.ajog.2020.06.022

Yong, P. S. A., \& Chen, X. (2020). Reducing droplet spread during airway manipulation: lessons from the COVID-19 pandemic in Singapore. British Journal of Anaesthesia, 125(1), e176-e178. 